\title{
Analisa Pangsa Pasar Produk Air Mineral Dalam Kemasan 240 MI Di Kelurahan Klawuyuk Kota Sorong Dengan Metode Markov Chain
}

\author{
Intan Iriani Supriatna ${ }^{1)}$, Ashar Ashar ${ }^{2)}$, Irman Amri $^{3)}$, Farlin ${ }^{4)}$ \\ 1),2),3),4) Program Studi Teknik Industri Universitas Muhammadiyah Sorong \\ Jalan Pendidikan No 27 Kota Sorong, Propinsi Papua Barat \\ Email : intanumsorong@gmail.com
}

\begin{abstract}
ABSTRAK
Metode Markov Chain (Rantai Markov) merupakan salah satu alat analisa yang dapat digunakan untuk memprediksi pangsa pasar (Market Share) produk untuk waktu tertentu di masayang akan datang beserta pola perubahan pasar yang akan terjadi hingga kondisi kemantapan/steadystate tercapai. Tujuan dari penelitian skripsi ini adalah untuk menganalisa faktor-faktor yang memungkinkan konsumen produk Air Minum Dalam Kemasan $240 \mathrm{ml}$ untuk beralih merek dari merek yang satu ke merek yang lain dengan menggunakan metode Marcov Chain. Penelitian ini dilakukan dengan cara menyebarkan kuisioner, yang bertujuan untuk mengetahui tentang konsumen dalam mengkonsumsi Air Minum Dalam Kemasan $240 \mathrm{ml}$ di waktu lalu dan sekarang sehingga dapat diketahui kriteria utama dalam pemilihan merek Air Minum yang diinginkan. Dari hasil analisa didapatkan perolehan pasar untuk masing-masing merek Air Minum Dalam Kemasan $240 \mathrm{ml}$ hingga kondisi kemantapan pasar, dimana merek Aqua masih tetap dapat mempertahankan posisinya sebagai marketleader,Tirmas mengalami kenaikkan di posisimarketchallenger, sementara Vit berubah menempati posisi marketfollower dengan perolehan pasar lebih rendah dibandingkan dengan periode sebelumnya, sementara Cendraqua tetap di posisinya marketnicher. Selain dari hasil analisa didapatkan perencanaan strategi pemasaran yaitu strategi pemasaran berdasarkan pangsa pasar. Untuk mengaplikasikan model Markov Chain ini, maka perusahaan harus melakukan penelitian pasar secara periodik, mengingat kondisi pasar yang sangat kompotitif dan terus berubah-ubah.
\end{abstract}

Kata Kunci : produk, pangsa pasar, markov chain

\section{PENDAHULUAN}

\section{Latar Belakang Masalah}

Dengan semakin banyaknya produk konsumsi, khususnya produk air minum dalam kemasan $240 \mathrm{ml}$ yang beredar dipasar dengan berbagai merek dan atribut, maka konsumen dihadapkan pada berbagai alternative pilihan dalam membeli produk air minum dalam kemasan 240 $\mathrm{ml}$ yang disukai. Konsumen biasanya lebih suka memilih produk air minum dalam kemasan 240 $\mathrm{ml}$ yang rasanya lebih segar dan tidak menimbulkan rasa yang berlainan. Ada juga konsumen yang menyukai produk air minum dalam kemasan $240 \mathrm{ml}$ dengan atribut produknya yang sudah sering di tayangkan di media. Namun kadang kala ada konsumen yang tidak mendapatkan apa yang diinginkannya pada atribut produk air minum dalam kemasan $240 \mathrm{ml}$ yang dikonsumsi sebelumnya, sehingga konsumen akan berpindah kemerek produk air minum dalam kemasan $240 \mathrm{ml}$ lain yang mungkin sesuai dengan keinginannya.

Hal-hal tersebut diatas adalah faktor-faktor yang memungkinkan konsumen untuk beralih Batasan Masalah merek dari merek yang satu kemerek yang lain. Untuk itu perilaku konsumen perlu diketahui oleh perusahaan dalam memproduksi suatu produk yang sesuai dengan keinginan konsumen, sehingga perusahaan tersebut dapat mempertahankan produknya di pasaran.

\section{Rumusan Masalah}

Dalam penelitian ini perumusan masalah didasarkan pada studi awal dan data, proses identifikasi dan analisa permasalahan. Analisa permasalahan dilakukan dengan mengakomodasi List of symptoms, identify root couses sampai dengan ditemukannya akar permasalahan yang melandasi penelitian. Perumusan masalah dalam penelitian ini yaitu :

1. Bagaimana pengaruh faktor kepercayaan, ketertarikan terhadap alternatif lain dan komitmen terhadap niatan perilaku konsumen untuk berpindah produk.

2. Bagaiman hubungan antar faktor-faktor tersebut terhadap niatan perilaku konsumen berpindah. 
Agar masalah yang dibangun dapat menggambarkan suatu system dan modelnya, maka perlu dibuat asumsi dan batasan masalah dalam penelitian ini adalah:

1. Objek penelitian yang dianalisis adalah mengkonsumsi atau pengguna produk air minum dalam kemasan $240 \mathrm{ml}$, dibatasi pada jumlah penduduk yang bertempat tinggal di Kelurahan Klawuyuk.

2. Merek produk air minum dalam kemasan $240 \mathrm{ml}$ yang dikonsumsi sebagai contoh kasus dalam penelitian ini adalah merek-merek air minum dalam kemasan 240 ml,Cendraqua, Tirmas, Vit dan Aqua.

3. Periode pengamatan atau perpindahan status ditetapkan untuk dua periode pembelian terakhir, yang diperkirakan \pm satu bulan. Hal ini dengan pertimbangan bahwa dalam selang waktu tersebut konsumen sudah dapat memilih untuk setiap ada satu merek atau berpindah kemerek yang lain berdasarkan pengalaman pemakaiannya.

4. Model rantai Markov yang digunakan dalam penelitian ini adalah first-order, dimana model ini banyak mempertimbangkan pilihan-pilihan merek yang dibuat selama satu periode untuk penentuan probabilitas pilihan dalam periode berikutnya.

5. Penelitian ini didasarkan pada perhitungan yang berasal dari data yang ada dan rasional, sedangkan data yang bersifat social dan politik yang mungkin mempengaruhi hasil penelitian berada di luar jangkauan peneliti.

Asumsi-asumsi yang berlaku adalah :

1. Dalam mengkonsumsi air minum dalam kemasan $240 \mathrm{ml}$, konsumen tidak mengubah pilihan dari satu merek kemerek yang lain secara acak. Merekmerek yang dibeli konsumen pada waktu yang akan datang mencerminkan pilihan yang dibuat pada waktu sebelumnya.

2. Tidak ada konsumen yang meninggalkan (tidak lagi membeli air minum dalam kemasan $240 \mathrm{ml}$ atau masuk sebagai konsumen baru).

3. Masing-masing merek yang ada memiliki kebijaksanaan tersendiri untuk merebut pangsa pasar.

Tujuan dan Manfaat Penelitian

Tujuan dan penelitian ini adalah sebagai berikut:

- Menganalisa faktor-faktor yang memungkinkan konsumen produk air minum dalam kemasan $240 \mathrm{ml}$ untuk beralih merek dari merek yang satu kemerek yang lain dengan menggunakan Metode Markov Chain,

- Selain dari hasil analisa didapatkan perencanaan strategi pemasaran yaitu strategi pemasaran berdasarkan pangsa pasar.

\section{METODOLOGI PENELITIAN Cambaran Populasi}

Bertitik tolak dari apa yang telah penulis uraikan sebelumnya, maka dalam penelitian ini yang menjadi populasi penelitian adalah para pengkonsumsi produk Air Minum Dalam Kemasan $240 \mathrm{ml}$ Lokasi tempat pengambilan data adalah Kelurahan Klawuyuk.

Menurut Kantor Kelurahan klawuyuk, dalam tahun 2013, terdapat 10.725 jiwa yang terdiri dari 2.810 Kepala Keluarga dengan jumlah laki-laki sebanyak 5.575 jiwa dan jumlah perempuan sebanyak 5.150 jiwa.

Untuk menentukan jumlah sampel yang harus diambil dalam penelitian ini, maka menurut Yamame (1.967) digunakan rumusan sebagai berikut :

$\mathrm{n}=\frac{N}{N d^{2}+1}$

Keterangan:

- Pada penelitian ini dipakai $0,052=5,2 \%$ - tingkat keyakinan $94,8 \%$

- d merupakan tingkat kesalahan maksimum, dimana diharapkan sebesar $\mathrm{O}, 052\left(\mathrm{~d}^{2}=0,0027\right)$

- $\mathrm{N}$ merupakan jumlah keseluruhan populasi penelitian, dalam hal ini sebesar 10.725 jiwa.

Sehingga perhitungan jumlah sampel yang diambil adalah sebagai berikut:

$\mathbf{1 0 . 7 2 5}$ 


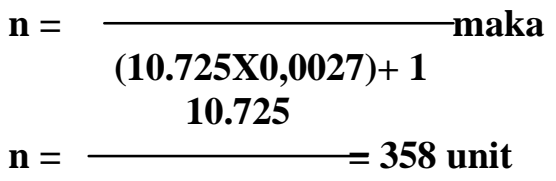

sampel $28,9575+1$

\section{Prosedur Pengumpulan dan Pengolahan} Data

Didalam penelitian ini digunakan beberapa metode dalam pengumpulan data. Metodemetode tersebut adalah sebagai berikut :

1. Studi kepustakaan yaitu suatu studi yang dilakukan diperpustakaan untuk mengumpulkan bahan referensi dan berbagai buku dan media internet.

2. Metode survei yaitu suatu metode pengumpulan data yang dilakukan dengan cara menyebarkan kuisioner.

\section{Analisa Data}

Metode-metode analisa data yang digunakan dalam penelitian ini adalah sebagai berikut:

- Analisa Markov Chain, Yaitu suatu metode yang dilakukan dengan menyusun Matriks Probability Transisidan. Model. Markov Chain (Rantai Markov) untuk mendapatkan prediksi pangsa pasar serta perubahan pasar yang terjadi hingga kondisi kemantapan (steadysiate) tercapai yang terjadi di wilayah Kelurahan Klawuyuk Distrik Sorong Timur.

Semua metode penulisan dan analisa dalam artikel ilmiah ini merujuk pada panduan penulisan tugas akhir Fakultas Teknik Universitas Muhammadiyah Sorong tahun 2014 (Pristianto, Amri, \& Rusdi, 2018).

\section{ANALISA PENGUMPULAN DAN PENGOLAHAN DATA}

\section{Pengumpulan Data}

Data yang diperoleh adalah data yang didapatkan dari kuisioner yang disebarkan kepada konsumen air minum dalam kemasan $240 \mathrm{ml}$ di kelurahan klawuyuk dan disebarkan secara acak. Pengumpulan data dilakukan selama dua bulan. Komposisi jumlah penduduk yang merupakanobjek penelitian dapat dilihat pada tabel 1 dibawah ini.

Tabel 1. Jumlah Penduduk Berdasarkan Lokasi

\begin{tabular}{ccc}
\hline No & Lokasi & $\begin{array}{c}\text { Jumlah } \\
\text { penduduk }\end{array}$ \\
\hline 1 & RW I & 565 \\
\hline 2 & RW II & 911 \\
\hline 3 & RW III & 1543 \\
\hline 4 & RW IV & 1340 \\
\hline 5 & RW V & 1443 \\
\hline 6 & RW VI & 1574 \\
\hline 7 & RW VII & 1471 \\
\hline 8 & RW VIII & 1825 \\
\hline \multicolumn{3}{c}{ Total } \\
\hline \multicolumn{5}{c}{}
\end{tabular}

Kuisioner yang disebarkan sebanyak 358 unit sampel dan jumlah yang dinyatakan valid sebanyak 358 unit sampel. Kriteria kuisioner dinyatak valid apabila semua pertanyaan yang diajukan terisi semua oleh responden dan responden mengerti isi dari pertanyaan yang disampaikan. Pada penelitian ini responden yang dipilih adalah para konsumen air minum dalam kemasan $240 \mathrm{ml}$, yang berdomisili diwilayah Kelurahan Klawuyuk Distrik Sorong Timur. Dari jumlah kuesioner yang valid, diperoleh tingkat responden $100 \%$, seperti dapat dilihat pada tabel

Tabel 2. Respon Konsumen Terhadap Kuisioner

\begin{tabular}{lc}
\hline \multicolumn{1}{c}{ Keterangan } & Jumlah \\
\hline Tersebar & 358 \\
\hline Rusak & 0 \\
\hline Tidak kembali & 0 \\
\hline Baik & 358 \\
\hline \multicolumn{1}{c}{ Tingkat respon } & 100 \\
\hline
\end{tabular}


Dari 358 kuesioner, input kuesioner yang valid untuk penelitian ini berjumlah 358 sampel (dapat dilihat pada tabel 2). Jumlah tersebut tentunya sudah cukup baik untuk metode pengumpulan data menggunakan kuisioner, sesuai perhitungan rumus diatas.

\section{Karakteristik Responden}

Karakteristik responden air minum dalam kemas $240 \mathrm{ml}$ diperoleh dari kuisioner bagian empat yang berisi data umum responden mengenai SDM, Status tempat tinggal, Mengkonsumsi air minum dalam kemasan $240 \mathrm{ml}$ sendiri ditempat tinggal?, serta Penghasilan perbulan. Karakteristik responden pada penelitian ini dapat dilihat pada tabel 3 .

Tabel 3. Rekapitulasi Karakteristik Responden

\begin{tabular}{|c|c|c|c|}
\hline \multicolumn{2}{|c|}{ Karakteristik Responden } & Jumlah & Presentasi \\
\hline Umum/ SDM & $\begin{array}{l}\text { - Pelajar/ Mahasiswa } \\
\text { - Pegawai Negeri } \\
\text { - Wiraswasta } \\
\text { - Ibu Rumah Tangga } \\
\text { - Pegawai Swasta } \\
\text { - Lainnya }\end{array}$ & $\begin{array}{c}113 \\
65 \\
58 \\
63 \\
51 \\
8\end{array}$ & $\begin{array}{l}32 \% \\
18 \% \\
16 \% \\
18 \% \\
14 \% \\
2 \%\end{array}$ \\
\hline $\begin{array}{l}\text { Status Tempat } \\
\text { Tinggal }\end{array}$ & $\begin{array}{l}\text { - Rumah Sendiri } \\
\text { - Kost } \\
\text { - Kontrak } \\
\text { - Rumah Dinas } \\
\text { - Rumah Keluarga/ Famili } \\
\text { - Lainnya }\end{array}$ & $\begin{array}{c}101 \\
76 \\
79 \\
39 \\
61 \\
2\end{array}$ & $\begin{array}{l}28 \% \\
21 \% \\
22 \% \\
11 \% \\
17 \% \\
1 \%\end{array}$ \\
\hline $\begin{array}{l}\text { Mengkonsumsi } \\
\text { AMDK } 240 \mathrm{ml} \\
\text { sendiri di tempat } \\
\text { tinggal? } \\
\end{array}$ & $\begin{array}{l}\text { - Ya } \\
\text { - Tidak } \\
\text { - Kadang-kadang } \\
\end{array}$ & $\begin{array}{c}134 \\
55 \\
169\end{array}$ & $\begin{array}{l}37 \% \\
15 \% \\
48 \%\end{array}$ \\
\hline $\begin{array}{l}\text { Penghasilan } \\
\text { Perbulan }\end{array}$ & $\begin{array}{l}\text { - Kurang dari Rp. } 150.000,- \\
\text { - Antara Rp. 150.000,- s/d Rp. } \\
350.000,- \\
\text { - Antara Rp. 350.000,- s/d Rp. } \\
\text { 550.000,-- } \\
\text { - Antara Rp. 550.000,- s/d Rp. } \\
\text { 750.000,- } \\
\text { - Antara 750.000,- s/d Rp. } 1 \text { Juta } \\
\text { Rupiah } \\
\text { - Lebih dari 1 Juta Rupiah }\end{array}$ & $\begin{array}{l}35 \\
28 \\
17 \\
45 \\
115 \\
118\end{array}$ & $\begin{array}{l}10 \% \\
8 \% \\
5 \% \\
12 \% \\
32 \% \\
33 \%\end{array}$ \\
\hline
\end{tabular}




\section{Analisa Markov Chain (Rantai Markov)}

Bertitik tolak dari pengumpulan data yang telah dilakukan, maka tabel 1 akan digunakan untuk menggambarkan pangsa pasar serta pola perubahan antar masing-masing merek air minum dalam kemasan $240 \mathrm{ml}$ yang dianalisa, dalam hal ini adalah air minum dalam kemasan 240 ml dengan merek, Aqua, Vit,

\section{a. Merek Aqua}

$$
\begin{aligned}
\text { Keterangan : A } & =\text { Aqua } \\
\mathrm{V} & =\text { Vit } \\
\mathrm{T} & =\text { Tirmas } \\
\mathrm{C} & =\text { Cendraqua }
\end{aligned}
$$

Tirmas, dan Cendraqua. Data dalam tabel tersebut dihitung berdasarkan pangsa pasar pada periode pembelian pada waktu $\mathrm{t}$ dan pada waktu $\mathrm{t}+1$, dimana dalam penelitian ini digunakan pangsa pasar air minum

\begin{tabular}{|c|c|c|c|c|c|c|c|c|c|}
\hline \multicolumn{4}{|c|}{ Berkurang ke merek } & \multirow{2}{*}{ Total } & \multicolumn{4}{|c|}{ Bertambah ke merek } & \multirow{2}{*}{ Total } \\
\hline $\mathrm{A}$ & $\mathrm{V}$ & $\mathrm{T}$ & $\mathrm{C}$ & & A & $\mathrm{V}$ & $\mathrm{T}$ & $\mathrm{C}$ & \\
\hline 0 & 20 & 17 & 19 & 56 & 0 & 15 & 17 & 19 & 51 \\
\hline
\end{tabular}
dalam kemasan $240 \mathrm{ml}$ bulan November dan Desember.

Tabel 4. Pola Perpindahan Jumlah Konsumen Aqua

\begin{tabular}{|c|c|c|c|c|c|c|c|c|c|}
\hline \multicolumn{4}{|c|}{ Berkurang ke merek } & Total & \multicolumn{4}{|c|}{ Bertambah ke merek } & Total \\
\hline A & $\mathrm{V}$ & $\mathrm{T}$ & $\mathrm{C}$ & & A & $\mathrm{V}$ & $\mathrm{T}$ & $\mathrm{C}$ & \\
\hline 17 & 0 & 15 & 13 & 45 & 17 & 0 & 14 & 20 & 51 \\
\hline
\end{tabular}

b. Merek Vit

Tabel 5. Pola Perpindahan Jumlah Konsumen Vit

\begin{tabular}{|c|c|c|c|c|c|c|c|c|c|}
\hline \multicolumn{4}{|c|}{ Berkurang ke merek } & \multirow{2}{*}{ Total } & \multicolumn{4}{|c|}{ Bertambah ke merek } & \multirow{2}{*}{ Total } \\
\hline $\mathrm{A}$ & $\mathrm{V}$ & $\mathrm{T}$ & $\mathrm{C}$ & & $\mathrm{A}$ & $\mathrm{V}$ & $\mathrm{T}$ & $\mathrm{C}$ & \\
\hline 22 & 17 & 0 & 15 & 54 & 22 & 23 & 0 & 13 & 58 \\
\hline
\end{tabular}

\section{c. Merek Tirmas}

Tabel 6. Pola Perpindahan Jumlah Konsumen Tirmas

\begin{tabular}{|c|c|c|c|c|c|c|c|c|c|}
\hline \multicolumn{4}{|c|}{ Berkurang ke merek } & \multirow{2}{*}{ Total } & \multicolumn{4}{|c|}{ Bertambah ke merek } & \multirow{2}{*}{ Total } \\
\hline A & $\mathrm{V}$ & $\mathrm{T}$ & $\mathrm{C}$ & & A & $\mathrm{V}$ & $\mathrm{T}$ & $\mathrm{C}$ & \\
\hline 12 & 9 & 19 & 0 & 30 & 12 & 11 & 21 & 0 & 44 \\
\hline
\end{tabular}

\section{d. Merek Cendraqua}

Tabel 7. Pola Perpindahan Jumlah Konsumen Cendraqua

Tabel 8. pangsa pasar periode awal masing-masing merek

\begin{tabular}{cc}
\hline Merek & Pangsa Pasar \\
\hline Aqua & $36,59 \%$ \\
\hline Vit & $29,33 \%$ \\
\hline Tirmas & $19,55 \%$ \\
\hline Cendraqua & $14,52 \%$ \\
\hline
\end{tabular}

Hasil Perhitungan Pangsa Pasar Untuk Periode Tiga (3) Bulan Mendatang

Tabel 9. Pangsa Pasar Masing-masing Merek Untuk Periode 3 Bulan Mendatang

\begin{tabular}{ccccc} 
Periode & Aqua (\%) & Vit (\%) & Tirmas (\%) & Cendraqua (\%) \\
\hline 1 & 32,27 & 21,40 & 17,41 & 9,59 \\
\hline 2 & 28,53 & 15,29 & 15,54 & 6,34 \\
\hline 3 & 25,22 & 11,03 & 13,86 & 4,19 \\
\hline & & \multicolumn{2}{c}{ Sumber : Kuisioner yang telah diolah }
\end{tabular}


Tabel 10. Estimasi Pangsa Pasar Hingga Kondisi Steady State Untuk Produk Air Minum Dalam Kemasan $240 \mathrm{ml}$ di Kelurahan Klawuyuk.

\begin{tabular}{ccccc}
\hline \multirow{2}{*}{ Periode } & \multicolumn{4}{c}{ Estimasi Pangsa Pasar (X 100 \%) } \\
\cline { 2 - 5 } & Aqua & Vit & Tirmas & Cendraqua \\
\hline 0 & 0,365 & 0,293 & 0,195 & 0,145 \\
\hline 1 & 0,3227 & 0,2118 & 0,1741 & 0,0959 \\
\hline 2 & 0,2853 & 0,1529 & 0,1554 & 0,0634 \\
\hline 3 & 0,2522 & 0,1103 & 0,1386 & 0,0419 \\
\hline 4 & 0,2229 & 0,0810 & 0,1237 & 0,0278 \\
\hline 5 & 0,2229 & 0,0810 & 0,1237 & 0,0278 \\
\hline 6 & 0,2229 & 0,0810 & 0,1237 & 0,0278 \\
\hline 7 & 0,2229 & 0,0810 & 0,1237 & 0,0278 \\
\hline 8 & 0,2229 & 0,0810 & 0,1237 & 0,0278 \\
\hline 9 & 0,2229 & 0,0810 & 0,1237 & 0,0278 \\
\hline 10 & 0,2229 & 0,0810 & 0,1237 & 0,0278 \\
\hline
\end{tabular}

Sumber : Kuisioner yang telah diolah

\section{KESIMPULAN}

Berdasarkan hasil penelitian diwilayah Kelurahan Klawuyuk Kota Sorong, maka dapat disimpulkan bahwa :

1. Hasil analisa kecenderungan pangsa pasar dari produk air minum dalam kemasan 240 $\mathrm{ml}$ dengan menggunakan metode Marcov Chain (Rantai Markov) :

a. Pada penelitian ini untuk produk Air minum dalam kemasan $240 \mathrm{ml}$ pada kelurahan Klawuyuk, pangsa pasar periode awal untuk merek Aqua $38,93 \%$ dan terus naik untuk tiap periode hingga sebesar 36,5\%.

b. kondisi kemantapan pada periode keempat yaitu 22,29\% sehingga Aqua tetap dapat mempertahankan posisinya sebagai Market leader.

c. Pangsa pasar periode awal untuk Tirmas $36,35 \%$ dan mengalami kenaikkan dari 19,5\% hingga stabil pada periode keempat yaitu 12,37\%, Tirmas naik pada posisi Market Challenger pada kondisi kemantapan pasar setelah Aqua.

d. Pangsa pasar periode awal untuk Vit mengalami penurunan yang cukup besar $72,35 \%$ dimana tingkat dari 29,3\% hingga mengalami sedikit kenaikan pada periode keempat yaitu $8,10 \%$, dengan demikian Vit dapat mempertahankan posisinya sebagai Market follower.

e. Pangsa pasar periode awal untuk Cendraqua mengalami penurunan sangat besar $80,82 \%$ dari kondisi awal 14,5\% kemudian menjadi 2,78\%, dengan demikian Cendraqua tetap pada posisinya sebagai Market Nicher. 
2. Strategi pemasaran yang perlu dilakukan yaitu Strategi pemasaran berdasarkan Perolehan pasar. Pada strategi ini ada dua pola yang dapat dipakai yaitu :

a. Pola menyerang (Attack) adalah strategi yang berusaha menurunkan pangsa pasar kompetitor agar pangsa pasar merek lain turun, dengan jalan berusaha merebut konsumen yang telah loyal pada merek lain tersebut sehingga konsumen yang loyal itu akan berpindah ke merek lain tersebut, dengan demikian akan menambah pangsa pasar yang telah ada.

b. Pola pertahanan (Defend) adalah berusaha menarik konsumen lain yang kurang loyal untuk mempertahankan pangsa pasar yang ada.

\section{DAFTAR PUSTAKA}

Achmad Yaqin, Hendrata.(2007), Analisa Pangsa Pasar Produk Deterjen Dengan Metode Marcov Chain. Tugas Akhir Fakultas Teknik Industri Unamin, Sorong

Kotler,Philip and Armstrong, Gaary. 1996. Principles Of Marketing. Seventh Edition. New Jersey: Prentice-Hall

Kotler, Philip (1986). Pemasaran, Analisis, Perencanaan dan Pengendalian, Jilid 1. edisi kelima, Penerbitan Erlangga, PT. Midas Surya Grafindo Jakarta

Nababan. M. (1988), Matematika Untuk Ilmu Ekonomi dan Bisnis Penerbit Erlangga, Jakarta .

Pristianto, H., Amri, I., \& Rusdi, A. (2018). Pedoman Penulisan Tugas Akhir Fakultas Teknik Universitas Muhammadiyah Sorong.

Siagian, P. (1987). Penelitian Operasional. Penerbit Universitas Indonesia (UIPRESS).

Widya, Imanesta.(2009), Analisa Profil Organisasi Balajar Pertamina Group. Tugas Akhir Departemen Teknik Industri ITB, Bandung. 